\title{
Effect of surrounding trees and dry rush presence on spring zooplankton community in an urban pond complex
}

\author{
Anna M. Basińska ${ }^{1,2,3 *}$, Kasper Świdnicki ${ }^{1}$ and Natalia Kuczyńska-Kippen ${ }^{1}$ \\ 1 Department of Water Protection, Faculty of Biology, Adam Mickiewicz University, Umultowska 89, 61-614 Poznań, Poland \\ 2 Department of Meteorology, Poznan University of Life Sciences, Piątkowska 94, 60-649 Poznań, Poland \\ 3 Laboratory of Wetland Ecology and Monitoring, Adam Mickiewicz University in Poznań, Dzięgielowa 27, 61-680 Poznań, Poland
}

Received 27 April 2014; Accepted 9 October 2014

\begin{abstract}
The role of both natural and artificial ponds in supporting biodiversity and as an infrequent habitat for aquatic organisms in urban areas may be greater than that in more rural landscapes. Moreover, biological succession and the dynamics of zooplankton can differ in urban ponds where we may observe a specific combination of environmental factors (e.g., an increase of eutrophication and pollution) compared to other water ecosystems. Therefore, ten urban artificial ponds were examined and the type of direct catchment area was established as the most important factor in the determination of zooplankton distribution. Different environmental factors structured zooplankton distribution between forest and meadow ponds. Low concentrations of oxygen as well as lack of fish, which was an effect of high concentrations of ammonium nitrogen, were responsible for the occurrence of littoral species and large crustacean species (e.g., Daphnia hyalina and Megacyclops viridis) in the case of forest ponds. Fish predation on large crustaceans and favourable food conditions (high concentration of chlorophyll a) created suitable conditions for the occurrence of pelagic species (e.g., Keratella cochlearis and K. quadrata) in the case of meadow ponds. Moreover, soon after the ice cover melted and before new macrophytes developed, previous-year dry rush stems created valuable refuge conditions for zooplankton in this type of pond. Despite anthropogenic pollution resulting from the close vicinity of the agglomeration of Poznań and unfavourable conditions attributed to the spring season a diverse zooplankton community occurred, reaching the level of 119 species in total.
\end{abstract}

Key words: Ponds' catchment area / fish predation / cladocerans / rotifers

\section{Introduction}

Small water bodies create a specific and unique aquatic environment. Owing to their low water volume and shallowness, ponds are more affected by environmental changes compared to lakes. The characteristics and management of both the direct and indirect catchment area may be reflected in the water physicochemistry and it has therefore a significant effect on the inhabiting organisms (Ejsmont-Karabin and Kruk, 1998; Dodson et al., 2007; Di Prinzio et al., 2009; Grochowska and Brzozowska, 2013). In particular, the presence of urban areas in the vicinity of aquatic ecosystem and rivers can decrease water quality as well as the biodiversity of plants and invertebrates (Allan, 2004; Declerck et al., 2006; De Paggi and Devercelli, 2011; Park et al., 2011). However, tree formations in the immediate neighbourhood of a pond may, by chemical and physical filtration,

\footnotetext{
*Corresponding author: basinska.a@gmail.com
}

buffer the inflow of pollutants from an urban catchment (Norris, 1993). On the other hand, falling leaves contribute a supply of organic matter to the water body (Sobczyński and Joniak, 2009) and can create an additional habitat for invertebrates. Moreover, instead of regarding the area and depth of ponds as restricted they may be divided into various microhabitats due to the occurrence of different macrophyte species that can build separate plant stands, even within a small area of a pond (Tessier et al., 2004). Therefore, it is not only the abundance of different small water bodies in landscapes, but also the macrophyte mosaic within a single pond that will support as well as contribute to the increase of biological diversity. The presence of macrophyte species has a significant influence on the species richness and community structure (Balayla and Moss, 2003; Iglesias et al., 2007; Ejsmont-Karabin and Hutorowicz, 2011; Dalu et al., 2012). Additionally, the different plant habitats are fundamental for particular groups of zooplankton, creating various life conditions and anti-predator refuges of varying effectiveness 


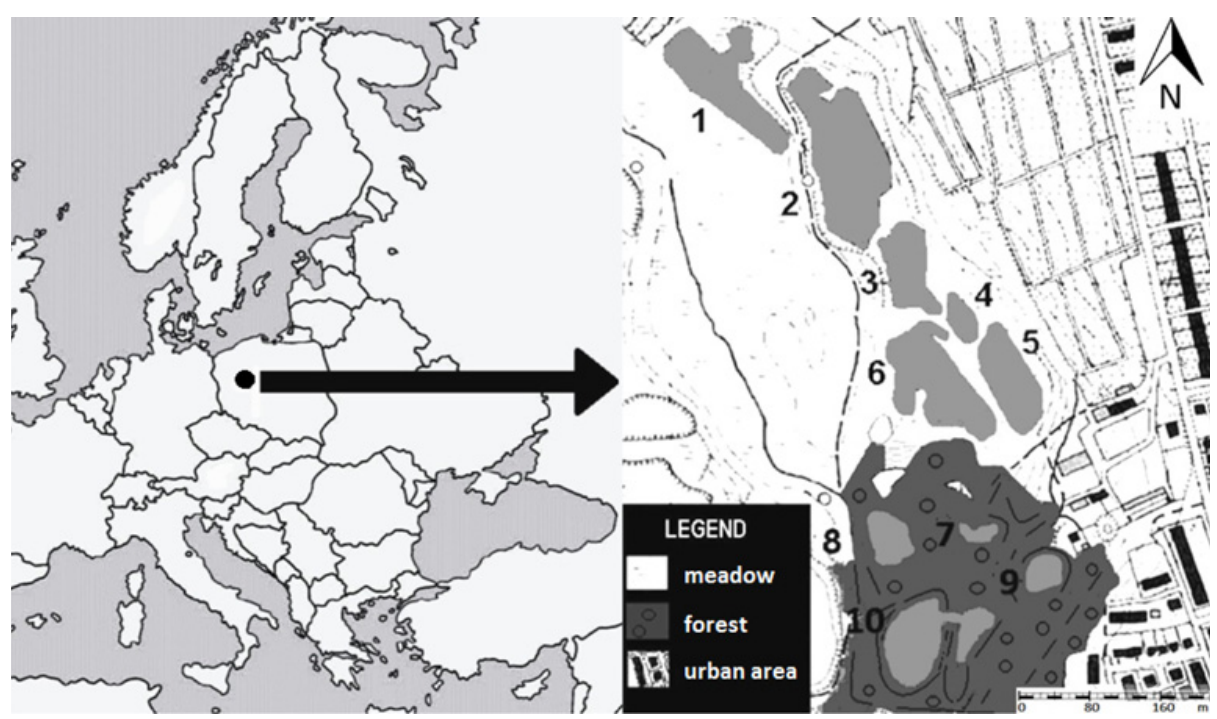

Fig. 1. The location of the city of Poznań (Poland) and detailed surrounding areas of studied ponds (geographical position for groups

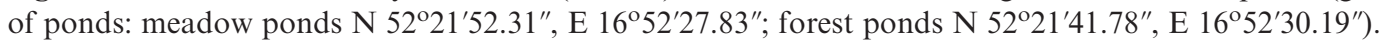

(Stansfield et al., 1997; Balayla and Moss, 2003; Špoljar et al., 2012).

Even though research on ponds has been often neglected we now realize that they make up a vital and specific aquatic habitat (Céréghino et al., 2008; Boix et al., 2012). Moreover, most research on small water bodies has concerned the summer season (Tõnno et al., 2003; Iglesias et al., 2007; Lucena-Moya and Duggan, 2011; McGavigan, 2012), when the majority of environmental factors, e.g., availability of a suitable food source or heterogeneity relating to the complexity of macrophyte cover, occur within optimum values. Hence, life conditions for inhabiting organisms are very advantageous at that time. Therefore, it was expected that during the spring season, when the study was carried out, the structure of zooplankton communities in the ponds would be less diverse in comparison with the summer. The spring season is also crucial for fish, which usually restrict zooplankton development in temperate climate zones. Most fish species in shallow macrophyte-dominated lakes and ponds begin to reproduce in March or April when the water temperature reaches $10^{\circ}$ (Brylińska, 1991). During the spring fish e.g., roach can have a great influence on zooplankton communities, even on those occurring among plant stands (Hansson et al., 2007; Nicolle et al., 2010).

Therefore, the general aim of this study was to identify the most important environmental factors (physiochemistry, predators, catchment area type and dry rush presence) structuring the zooplankton community in a set of urban ponds during the spring period.

Considering the two aspects relating to the type of pond catchment and predation pressure we hypothesized that (1) even though the ponds were located within a short distance of each other and were of the same origin the effect of direct tree formations, or their absence, will be significant for the zooplankton structuring in ponds, and (2) predators would be responsible for the zooplankton species distribution within habitat.

\section{Material and methods}

\section{Study site}

The examined ponds are situated within the administrative borders of the city of Poznan in the Wielkopolska region (Western Poland). This complex of ten ponds resulted from the clay extraction which took place in this area over a hundred years ago. Since this time the whole area has been exposed to indifferent management and the inflow of various types of pollutants originating from municipal wastewater rich in organic matter and nutrients. This in turn has had a significant impact on the increase of trophic conditions, deterioration of water quality and an intense growth of aquatic and wetland vegetation within the area (Pawuła-Piwowarczyk, 1992). In the examined ponds, defined as meadow types, macrophyte beds (e.g., Ceratophyllum demersum L., Utricularia vulgaris L., Phragmites australis (Cav.) Trin. ex Steudel and Typha angustifolia L.) were present from the end of the spring season (end of May - beginning of June) to the end of autumn. However, the present study was carried out in April when new aquatic vegetation has not yet been developed, as the ice cover had only recently disappeared in the Wielkopolska region and only old and dry shoots of rushes were still present.

The examined clay-pits were situated within a very short distance from each other (between 2 and $20 \mathrm{~m}$ ), however, the surroundings of particular ponds, as regards the percentage of trees, divided the direct catchment area in two separate groups: forest and meadow (Fig. 1; Table 1).

Thus, four ponds were situated within an old park and as the percentage of the tree coverage (e.g., Acer platanoides L., A. pseudoplatanus L., Corylus avellana L. and Alnus glutinosa Gaertn.) in their neighbourhood was high, accounting for $85 \%$, they were classified as forest ponds. The high density of trees around these ponds hindered the growth of rush vegetation but provided an 
Table 1. Average values of limnological parameters between different types of water bodies with additional helophyte habitat in meadow ponds. Trees reflect the percentage cover of closest pond surroundings. TP - total phosphorus.

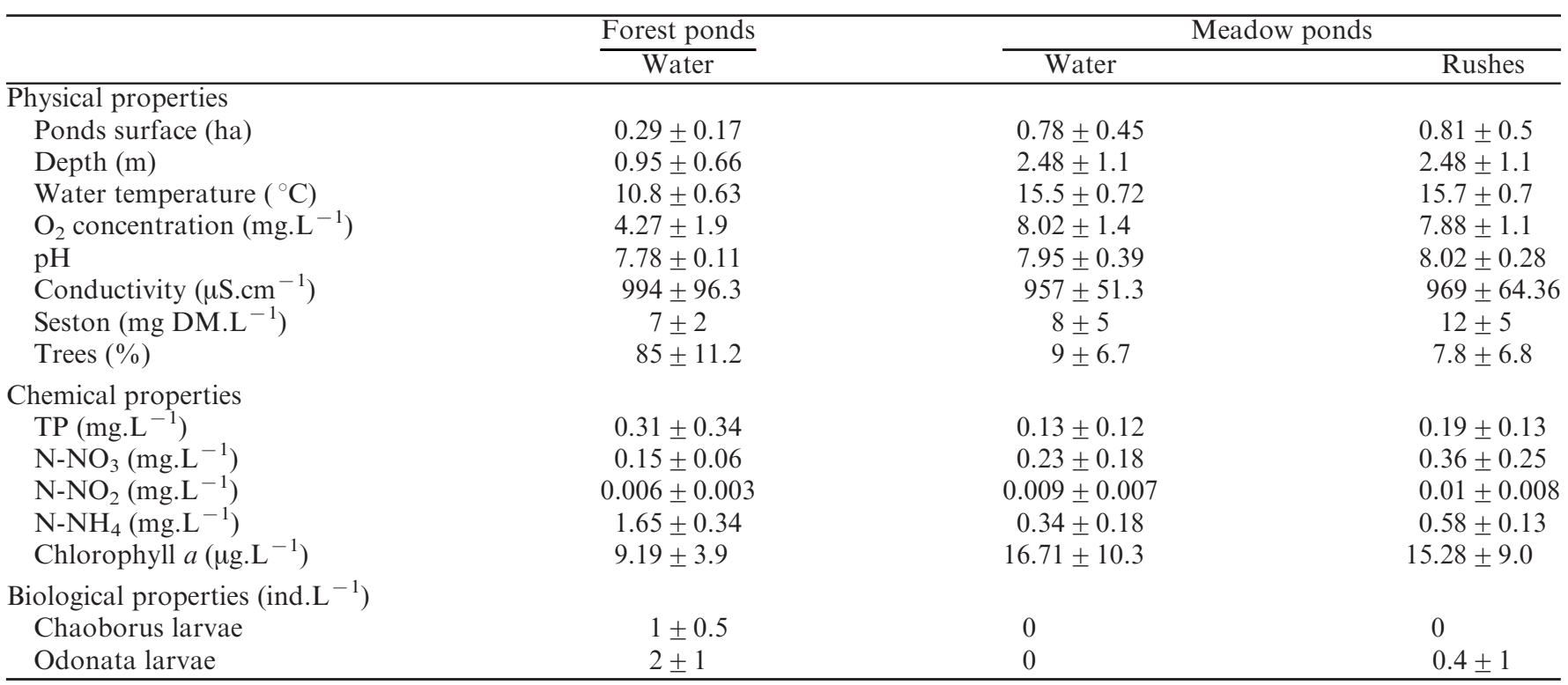

abundant supply of leaves which created a thick layer of leaf litter on the bottom throughout the year.

The second group of water bodies consisted of six ponds where only single trees were in the direct catchment area were referred to as meadow ponds. They were surrounded by a helophyte belt (mainly composed by Phragmites australis with a small participation of Typha angustifolia), wastelands and meadows. These water bodies were larger and deeper compared to the forest ponds (Table 1). They were abundantly inhabited by fish, contrary to the forest ponds where fish were not observed (in one pond) or occurred only in very small densities (in three ponds). The fish species frequently encountered in macrophyte-dominated small water bodies in Poland are: crucian carp (Carassius carassius L.), roach (Rutilus rutilus L.), rudd (Scardinius erythrophthalmus L.) and perch (Perca fluviatilis L.) (Brylińska, 1991).

In the forest ponds filamentous chlorophytes dominated, with a smaller participation of diatoms, chrysophytes and dinoflagellates. In the meadow clay-pits algae, assemblages were more diverse with a dominance of diatoms (in two ponds), chrysophytes and diatoms (in three ponds) and filamentous chlorophytes along with diatoms (in one pond), depending on the pond.

\section{Field and laboratory methods}

The field study was carried out over three consecutive days in the spring period (April) of 2009. In order to avoid vertical differentiation in abiotic parameters and zooplankton distribution samples were collected from the surface layer in the open water stations of each water body. 20-L (pelagic) and 5-L (littoral) samples were taken in triplicate using a calibrated vessel. Each sample was concentrated using a $45-\mu \mathrm{m}$ plankton up to 20 or $5 \mathrm{~mL}$, respectively and fixed immediately with $4 \%$ formaldehyde. The zooplankton species abundance was expressed as the number of individuals per Litre. Moreover, in the case of meadow ponds the dry rush stems were cut from the same water volume at every littoral station. Subsequently, the collected shoots were measured and weighed after drying in $80^{\circ} \mathrm{C}$ to obtain the biometric parameters of the rush stands. Individuals were identified to species level using keys (Flößner, 2000; Radwan et al., 2004; Rybak and Błędzki, 2010). Only Bdelloidea, Harpacticoida, Chaoborus and Odonata larvae were not identified to the species level.

Dominant groups in phytoplankton assemblage (Bacillariophyceae, Chlorophyceae, Dinophyceae) were identified using a scaled Olympus microscope in order to characterize the available food sources for zooplankton in both groups of ponds (Starmach, 1989).

Temperature, $\mathrm{pH}$, conductivity and oxygen concentration were measured in situ and water for chemical analyses was taken from same stations. Laboratory determination of the concentration of nitrogen and phosphorus forms as well as on chlorophyll $a$ concentration was conducted according to APHA (1998). In order to measure the dry mass of seston in water, samples were filtrated through glass-fibre filters. The dried filter weight was measured before and after filtration.

\section{Data analysis}

To compare species richness and the abundance of zooplankton groups between the two types of ponds: meadow versus forest $(n=30)$ and between two types of habitats: water versus rush zone $(n=36)$ the nonparametric $U$ Mann-Whitney's test was used. The nonparametric $U$ Mann-Whitney's test was also applied for 
Table 2. Average abundance (ind. $\mathrm{L}^{-1}$ ) and diversity (species number) in two pond types (Mann-Whitney $U$ test, $P<0.05$ ).

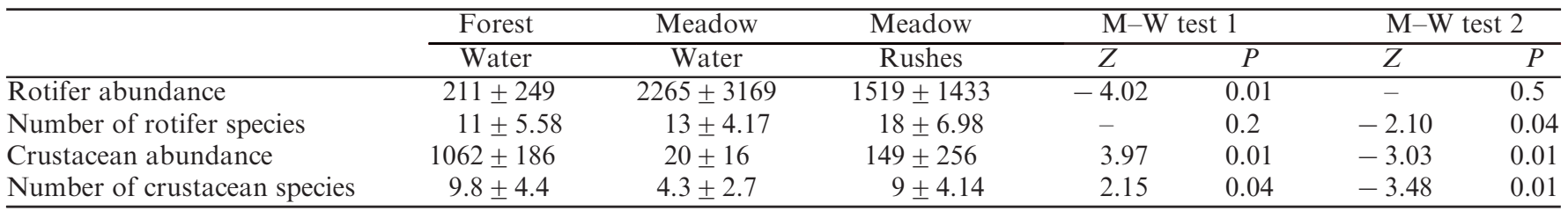

M-W test 1 - Mann-Whitney $U$ test: results concerning differences between zooplankton communities inhabiting open water (Water) of forest and meadow water bodies.

M-W test 2 - Mann-Whitney $U$ test: results concerning differences between zooplankton communities inhabiting open water (Water) and rushes (Rushes) of meadow water bodies.

comparison of physicochemical parameters between the pelagic area of the two types of ponds: meadow versus forest $(n=30)$.

To study the biotic relationship between particular taxa of zooplankton and invertebrate predators as well as the morphometric features of a macrophyte habitat (stem length and mass), Spearman's Correlation Coefficient was applied.

To describe the environmental preferences of particular species, Redundancy Analysis (RDA) CANOCO 4.5 software (Lepš and Šmilauer, 2003) was applied. We used square-root data transformation and automatic selection in the procedure. The Monte Carlo Permutation Test (MCPT) of 999 permutations was used to test statistical significance. Rarely occurring species were excluded from the RDA analysis. Zooplankton species, which occurred in the examined material with at least $30 \%$ frequency, were taken into consideration. Fish presence and invertebrate predator numbers were also considered in the redundancy analysis.

\section{Results}

\section{Environmental characteristics}

The physiochemical parameters differed in relation to the type of pond surroundings. Forest ponds, shallower and of smaller area on average, were characterized by higher concentrations of ammonium $(Z=4.62 ; P<0.005)$, TP $(Z=2.18 ; P<0.05)$ and lower oxygen concentrations $(Z=-4.69 ; P<0.005)$ in the pelagic zone. In meadow ponds higher, $\mathrm{pH}$ values $(Z=-2.18 ; P<0.05)$, oxygen $(Z=-4.69 ; \quad P<0.005)$ and nitrate concentrations $(Z=-2.09 ; P<0.05)$ were found (Table 1$)$.

\section{Zooplankton characteristics in the open water of forest and meadow ponds}

119 zooplankton species were found in total (Rotifera 71 , Cladocera - 27, Copepoda - 20) in the ten examined ponds during the spring examination with 79 species in forest and 66 in meadow ponds, respectively.

Moreover, the mean number of species differed in relation to the type of pond surroundings. The meadow ponds were characterized by a higher diversity of rotifers and a significantly lower crustacean diversity compared to the forest ponds (Table 2).

Lecane (five species), Keratella (four species), Polyarthra (four species), Brachionus (three species) and Mesocyclops (three species) were the most diverse genera in the meadow clay-pits, while Cephalodella (six species), Acanthocyclops (six species) and Daphnia (five species) predominated in the forest water bodies.

Analysing the abundance distribution between both types of ponds it was found that rotifers were significantly more abundant in the meadow ponds and crustaceans prevailed in forest ponds (Table 2). Among rotifers forest ponds were characterized by the dominance of Notholca acuminata and bdelloids. Furthermore, crustaceans such as Bosmina longirostris, Daphnia hyalina and Megacyclops viridis occurred each with more than $10 \%$ of the total crustacean abundance in this set of ponds. In meadow ponds, a strong domination of rotifers was found, especially that of Asplanchna priodonta, Keratella cochlearis and $K$. quadrata, each of which contributed more than $20 \%$ to the total rotifer abundance.

\section{Spatial differentiation between the open water and rush zone in meadow ponds}

Both rotifers and crustaceans built more diverse assemblages within the zone of rushes in comparison with the open water zone within the meadow ponds (Table 2). Additionally, zooplankton abundances differed between these two types of habitat. Total abundance of crustaceans was significantly higher in rushes. Rotifers dominated in the pelagic zone, but these differences were not significant (Table 2).

Furthermore, the abundances and diversity of some rotifer (Brachionus calyciflorus, Pompholyx complanata) and cladoceran (Acroperus harpae, Ceriodaphnia pulchella, Scapholeberis mucronata and Sida crystallina) species (Table 3) correlated positively with the length $\left(0.195 \pm 0.1 \mathrm{~m} . \mathrm{L}^{-1}\right)$ and dry mass $\left(0.611 \pm 0.3 \mathrm{~g} . \mathrm{L}^{-1}\right) \mathrm{rush}$ stems which overwintered in the ponds.

\section{Relationships between environmental characteristics and zooplankton}

The results of multivariate analysis and the Monte Carlo test identified the forest type of pond catchment, 
Table 3. Significant Spearman correlation coefficients $(P<0.05)$ between biocoenotic features of zooplankton and environmental parameters: water temperature $-{ }^{\circ} \mathrm{C}$, plant stem length $-\mathrm{cm} \cdot \mathrm{L}^{-1}$ and dry mass $-\mathrm{g} . \mathrm{L}^{-1}$. Additionally, the relation with invertebrate predator numbers (Chaoborus and Odonata larvae ind. $\mathrm{L}^{-1}$ ).

\begin{tabular}{|c|c|c|c|c|c|}
\hline & Temperature & $\begin{array}{l}\text { Stem } \\
\text { length }\end{array}$ & $\begin{array}{c}\text { Stem } \\
\text { dry mass }\end{array}$ & $\begin{array}{c}\text { Chaoborus } \\
\text { larvae }\end{array}$ & $\begin{array}{c}\text { Odonata } \\
\text { larvae }\end{array}$ \\
\hline Rotifer abundance & 0.6 & & & & \\
\hline Number of rotifer species & & 0.4 & 0.4 & & \\
\hline Cladoceran abundance & -0.4 & & & & 0.3 \\
\hline Number of cladocerans species & & 0.4 & 0.4 & & \\
\hline Copepods abundance & -0.5 & & & & \\
\hline Number of copepods species & -0.3 & & & & \\
\hline Asplanchna priodonta & 0.6 & 0.3 & & & \\
\hline Bdelloidea & -0.4 & & & & \\
\hline Brachionus angularis & 0.5 & & & & \\
\hline Brachionus calyciflorus & 0.6 & & & & 0.3 \\
\hline Keratella cochlearis & 0.6 & & & & \\
\hline Keratella quadrata & 0.5 & & & & \\
\hline Lepadella quadricarinata & -0.4 & & & & \\
\hline Notholca acuminata & -0.7 & & & & \\
\hline Pompholyx complanata & 0.4 & 0.4 & 0.4 & & \\
\hline Acroperus harpae & & 0.5 & 0.5 & & \\
\hline Bosmina longirostris & & & & & 0.3 \\
\hline Ceriodaphnia pulchella & & 0.6 & 0.6 & & \\
\hline Daphnia cucullata & -0.3 & -0.3 & -0.3 & 0.3 & \\
\hline Daphnia hyalina & -0.3 & & & 0.4 & 0.3 \\
\hline Daphnia pulex & -0.6 & -0.3 & -0.3 & 0.3 & \\
\hline Scapholeberis mucronata & & 0.3 & 0.3 & & \\
\hline Sida crystallina & & 0.6 & 0.6 & & \\
\hline Harpacticoida & -0.3 & & & 0.3 & \\
\hline Megacyclops viridis & -0.6 & & & & \\
\hline Thermocycylops oithonoides & -0.3 & & & & 0.4 \\
\hline
\end{tabular}

seston and conductivity as significant factors for the zooplankton distribution pattern (Fig. 2; Table 4).

Two groups of zooplankton species could be identified from the RDA plot. The first group, in forest ponds, relating to the higher percentage of trees in the direct catchment area and higher ammonium concentration, was formed exclusively of crustacean species (both pelagic and littoral). In the forest ponds rotifers, excluding Notholca (pelagic), were represented by littoral taxa (e.g., bdelloids, Lepadella quadricarinata). The forest-associated crustaceans (representatives of Daphnia genus, C. sphaericus and copepods) also displayed a negative relationship with oxygen content, $\mathrm{pH}$ and morphometric features such as pond depth and size (Fig. 2). Furthermore, abundance of L. quadricarinata, Harpacticoida, Bdelloidea and C. sphaericus were positively related to total phosphorus content.

The second group, related to meadow ponds, was characterized by the dominance of pelagic rotifers of the genus Polyarthra and B. calyciflorus, which showed a positive relationship with seston content. $B$. angularis and $F$. terminalis correlated positively with chlorophyll $a$, nitrate and nitrite concentrations, while they were negatively associated with ammonium concentration. Moreover, Spartina pectinata was shown to have a positive relationship with water conductivity, nitrate and nitrite concentrations.
The abundance of particular zooplankton species was additionally analysed in relation to fish presence in all ponds. Daphnia pulex $(Z=-4.1 ; P<0.01)$, Harpacticoida $(Z=-2.8 ; \quad P<0.01)$ and $M$. viridis $(Z=-1.9 ; P<0.05)$ were found in significantly higher abundances in fishless forest ponds. Contrary to this, both rotifer diversity $(Z=2.8 ; P<0.01)$ and their abundance $(Z=2.6 ; P<0.01)$ were significantly higher in meadow ponds with fish.

The invertebrate predators (Chaoborus and Odonata larvae) and zooplankton species abundances showed only a positive correlation, e.g., the crustacean and copepod abundance increased with Odonata larvae abundance (Fig. 2; Table 3).

\section{Discussion}

The results of our study showed that despite the fact that the ten investigated small water bodies were located within the area of the Poznań agglomeration and had been exposed to urban pollution and degradation for decades, their species composition was highly diverse (119 species). We presume that this is a consequence of the occurrence of zooplankters with various life-cycles during this season, including low water temperature associated cryophilic (such as e.g., N. acuminata, P. dolichoptera and M. viridis), 


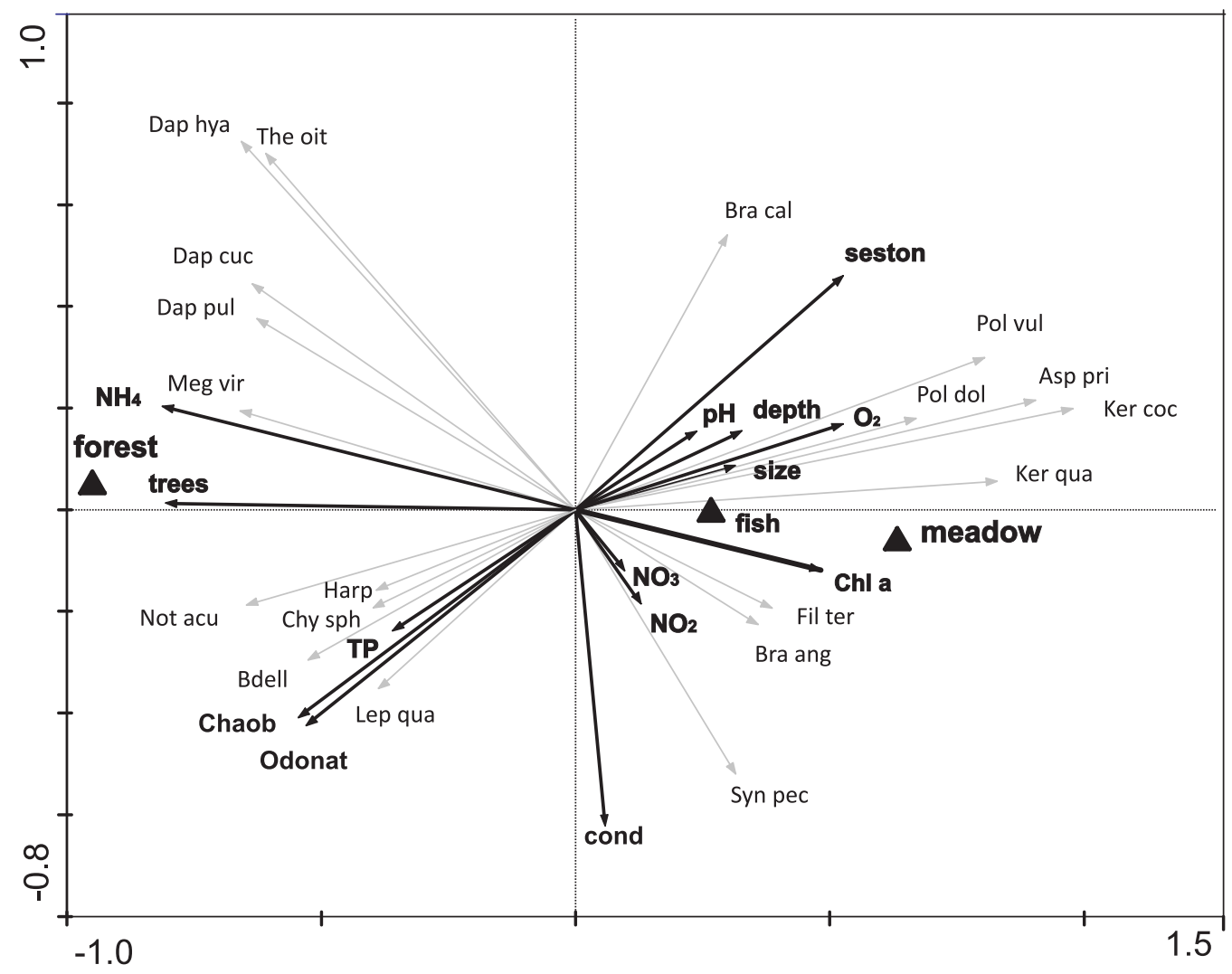

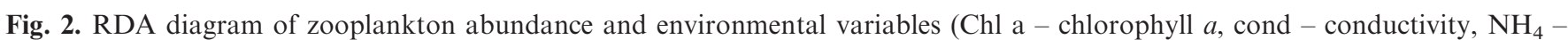
ammonium, $\mathrm{NO}_{3}$ - nitrate, $\mathrm{NO}_{2}$ - nitrite, $\mathrm{O}_{2}$ - oxygen concentration, $\mathrm{pH}$ - water reactivity, $\mathrm{TP}$ - total phosphorus, trees - percentage of trees in the pond surroundings, size and depth - morphometric features of a pond), Chaob - Chaoborus sp. Larvae, Odonat Odonata larvae, meadow and forest - pond surroundings, fish - presence. Rotifers: Asp pri - Asplanchna priodonta (Gosse 1850), Bdell - Bdelloidea (Hudson 1884), Bra ang - Brachionus angularis (Gosse 1851), Bra cal - B. calyciflorus (Pallas 1766), Fil ter - Filinia terminalis (Plate 1886), Ker coc - Keratella cochlearis (Gosse 1851), Ker qua - K. quadrata (Müller 1786), Lep qua - Lepadella quadricarinata (Stenroos 1898), Not acu - Notholca acuminata (Ehrenberg 1832), Pol dol - Polyarthra dolichoptera (Idelson 1925), Pol vul - P. vulgaris (Carlin 1943), Syn pec - Synchaeta pectinata (Ehrenberg 1832). Crustaceans: Chy sph - Chydorus sphaericus (O. F. Müller 1776), Dap cuc - Daphnia cucullata (G. O. Sars 1862), Dap hya - D. hyalina (Leydig 1860), Dap pul - D. pulex (Leydig 1860), Harpac - Harpacticoida (Sars 1903), Meg vir - Megacyclops viridis (Jurine 1820), The oit - Thermocyclops ointhonoides (G. O. Sars 1863).

thermophilic (e.g., P. complanata and P. vulgaris) as well as eurythermic species (e.g., K. cochlearis and S. pectinata) (Radwan et al., 2004). Environmental variables which are responsible for structuring zooplankton communities may be specific in the spring season when the weather conditions can be poor and few complex habitats are available for the inhabiting organisms. It was found that the most significant factor responsible for the zooplankton assemblage was the presence of surrounding forest. Therefore, a strict division of species groups into two types of ponds: forest, those with a large density of trees in the immediate surroundings and meadow, those lacking nearby trees, was confirmed.

The majority of large crustaceans, such as daphnids, were present in the open water area of forest ponds. This was possibly related to an absence of fish pressure caused by specific morphometric features (small and very shallow ponds) and unfavourable oxygen conditions. Hanazato and Yasuno (1989) and Lampert et al. (2010) suggested that Daphnia adults, which often overwinter, can build their populations faster than smaller zooplankton forms, which possibly happened in the case of the studied forest ponds. Additionally, the occurrence of some littoral species, such as e.g., M. viridis which is known to be well adapted for living in ponds characterized by rich organic matter and oxygen deficiencies, proves these arguments (Tinson and Laybourn-Parry, 1985; Rybak and Błedzki, 2010). In the forest ponds, a high concentration of ammonium was also observed, which is likely to have come from leaf decomposition in anaerobic conditions. Leaf litter presence can contribute to an increase in both phosphorus and nitrogen content in ponds (Sobczyński and Joniak, 2009). The litter sediments have created an additional habitat for littoral species present in forest ponds. The only pelagic rotifer which dominated in this type of pond was $N$. acuminata, which is a typical coldstenotherm species and is known to favour lower $\mathrm{pH}$ levels (Radwan et al., 2004). 
Table 4. Monte Carlo test for the significance of environmental factors in the zooplankton assemblage. Variables that appeared are marked in bold. Legend: cond - water conductivity, fish presence/absence, size - pond area, trees - percentage of trees in pond surroundings.

\begin{tabular}{|c|c|c|c|}
\hline \multicolumn{4}{|c|}{ Conditional effects } \\
\hline Variable & LambdaA & $P$ & $F$ \\
\hline Forest & 0.47 & 0.001 & 7.16 \\
\hline Seston & 0.18 & 0.004 & 3.45 \\
\hline Cond & 0.16 & 0.005 & 5.4 \\
\hline Fish & 0.06 & 0.098 & 2.08 \\
\hline Size & 0.02 & 0.463 & 1 \\
\hline Trees & 0.05 & 0.105 & 2.46 \\
\hline $\mathrm{pH}$ & 0.02 & 0.419 & 1.18 \\
\hline $\mathrm{O}_{2}$ & 0.02 & 0.434 & 1.3 \\
\hline Depth & 0.02 & 1 & 0 \\
\hline
\end{tabular}

Different environmental factors structured zooplankton in the meadow ponds. Among them were factors, which either directly or indirectly affected zooplankton, e.g., the quality of food or the effect of nutrient recycling (Sterner, 1989; Symons et al., 2012). In the case of the studied meadow clay-pits, where algae assemblages were diverse (with a dominance of diatoms, chrysophytes or filamentous chlorophytes), only pelagic rotifers occurred. Abundance of these rotifer species positively associated with phytoplankton biomass, represented by chlorophyll $a$ concentration (B. angularis and F. terminalis) and seston content in water (Polyarthra species and B. calyciflorus). Moreover, the obtained results may also be related to the food requirements of these rotifers. They are microfilterfeeders, which mainly live on detritus along with associated bacteria, however, they also often utilize algae, especially representatives of Chlorococcales, diatoms and chrysophytes (Pourriot, 1970, 1977; RuttnerKolisko, 1980), dominated in the meadow ponds. On the other hand $F$. terminalis, A. priodonta, K. quadrata, and Polyarthra spp., reach their highest densities at high oxygen concentrations (Elliott, 1977), which was found to be the case in all the meadow ponds.

The Hanazato and Yasuno (1989) as well as Warfe and Barmuta (2004) suggest that in small water bodies a various combination of both vertebrate and/or invertebrate predators lead to a high diversity of zooplankton community structure. In the investigated ponds, invertebrate predators (Chaoborus and Odonata larvae) seem to have no strong negative impact on structuring either the rotifer or crustacean densities in the spring season. This was confirmed by the positive relationship between the abundance of zooplankton and this group of predators. Furthermore, large crustaceans such as D. pulex, M. viridis as well as Harpacticoida prevailed in the forest clay-pits where fish predation was of much weaker impact compared to the meadow ponds. Large crustaceans can make up a favourable food source for most fish inhabiting small water bodies as observed in the examined meadow ponds during the spring season, where fish commonly occur. This is a likely explanation for the dominance of small zooplankton taxa, i.e., rotifers, in this group of investigated ponds. In spring, at the beginning of the vegetation season, macrophyte consists only of the previous-year's dry shoots. According to Hansson et al. (2007) and Nicolle et al. (2010) they do not provide a very efficient refuge for zooplankton organisms as fish are able to penetrate them. It was therefore expected that zooplankton in such simple and loose remains of rush vegetation, would not fare very differently from those in the homogenic open water area. However, the results of our study indicated that despite the fact that the littoral was composed only of dry stems of architecturally uncomplicated $P$. australis significant differences in zooplankton assemblages were found between the two studied habitats. Both rotifers and crustaceans were built with more diverse assemblages within the zone of rushes. Moreover, the total abundance of crustaceans was higher in the rushes, which shows that even such a poor architectural habitat creates perfect refuge conditions for large fractions of zooplankton, which constitute a preferred food source for fish.

We found that a variety of both littoral cladocerans (e.g., C. pulchella and S. crystallina) as well as two species of pelagic rotifers (B. calyciflorus, $P$. complanata) were positively related to the biometric features of the helophyte stand, dry mass and rush stem length, which reflect the complexity of the plant habitat (Lucena-Moya and Duggan, 2011).

To sum up, the most important factor for the urban ponds' zooplankton community during the spring period is the reflection of the direct catchment area. The distribution of zooplankton between the two sets of ponds can be directly attributed to the type of catchment area, seston concentration and conductivity. Various factors are responsible for zooplankton occurrence in the forest ponds (e.g., low concentrations of oxygen and lack of fish resulting from high concentrations of ammonium nitrogen) and meadow ponds (e.g., the presence of fish and better food conditions). Furthermore, the presence of additional habitats such as dry rush shoots had an impact on the within-pond distribution pattern of rotifer and crustacean distribution in the case of meadow water bodies, creating an anti-predator refuge for larger zooplankters. We also found that taxonomic composition may be rich even though the studied ponds were susceptible to degradation through being situated within an area of high anthropogenic transformation resulting from the closely neighbouring agglomeration of the city of Poznań. The crucial factor which supported zooplankton diversity and abundance was the presence of various microhabitats in the littoral zone and a great deal of detritus, presented as leaf litter and decomposed rush.

Acknowledgements. This research work has been partly financed by the Polish State Committee for Scientific Research in 2010-2013 as research project N N305 042739. Authors thank Łukasz Lamentowicz, for help with statistical analysis. Anna Basińska was supported by the European Social Fund ('Scholarship support for PhD students specializing in majors strategic for Wielkopolska's development', Sub-section 8.2.2 
Human Capital Operational Programme, co-financed by the European Union under the European Social Fund).

\section{References}

Allan J.D., 2004. Influence of land use and landscape setting on the ecological status of rivers. Limnetica, 23, 187-198.

American Public Health Association, American Water Works Association, and Water Environment Federation, 1998. Standard Methods for the Examination of Water and Wastewater (20th edn,), American Public Health Association, Washington, DC, 1183 p.

Balayla D.J. and Moss B., 2003. Spatial patterns and population dynamics of plant-associated microcrustacea (Cladocera) in an English shallow lake (Little Mere, Cheshire). Aquat. Ecol., 37, 417-435.

Boix D., Biggs J., Céréghino R., Hull A.P., Kalettka T. and Oertli B., 2012. Pond research and management in Europe: "Small is Beautiful". Hydrobiologia, 689, 1-9.

Brylińska M., 1991. Freshwater fishes of Poland (Ryby słodkowodne Polski), Polish Scientific Publishers PWN, Warsaw, $521 \mathrm{p}$.

Céréghino R., Biggs J., Oertli B. and Declerck S., 2008. The ecology of European ponds: defining the characteristics of a neglected freshwater habitat. Hydrobiologia, 597, 1-6.

Dalu T., Clegg B. and Nhiwatiwa T., 2012. Macroinvertebrate communities associated with littoral zone habitats and the influence of environmental factors in Malilangwe Reservoir, Zimbabwe. Knowl. Manag. Aquat. Ecosyst., 406, 5-15.

Declerck S., De Bie T., Ercken D., Hampel H., Schrijvers S., Van Wichelen J., Gillard V., Mandiki R., Lossonf B., Bauwens D., Keijers S., Vyverman W., Goddeeris B., De Meester L., Brendonck L. and Martens K., 2006. Ecological characteristics of small farmland ponds: associations with land use practices at multiple spatial scales. Biol. Conserv., 131, 523-532.

De Paggi S.B. and Devercelli M., 2011. Land use and basin characteristics determine the composition and abundance of the microzooplankton. Water Air Soil Poll., 218, 93-108.

Di Prinzio C.Y., Casaux R.J. and Miserendino M.L., 2009. Effects of land use on fish assemblages in Patagonian low order streams. Ann. Limnol. - Int. J. Lim., 45, 267-277.

Dodson S.I., Everhart W.R., Jandl A.K. and Krauskopf S.J., 2007. Effect of watershed land use and lake age on zooplankton species richness. Hydrobiologia, 579, 393-399.

Ejsmont-Karabin J. and Hutorowicz A., 2011. Spatial distribution of rotifers (Rotifera) in monospecies beds of invasive Vallisneria spiralis L. in heated lakes. Oceanol. Hydrobiol. St., 40, 71-76.

Ejsmont-Karabin J. and Kruk M., 1998. Effects of contrasting land use on free-swimming rotifer communities of streams in Masurian Lake District, Poland. Hydrobiologia, 387-388, 241-249.

Elliott J.I., 1977. Seasonal changes in the abundance and distribution of planktonic rotifers in Grasmere (English Lake District). Freshw. Biol., 7, 147-166.

Flößner D., 2000. Die Haplopoda und Cladocera Mitteleuropas, Backhuys Publishers, Leiden, 428 p.

Grochowska J.K. and Brzozowska R., 2013. The influence of different recultivation methods on the water buffer capacity in a degraded urban lake. Knowl. Managt. Aquatic Ecosyst., $410,01$.

Hanazato T. and Yasuno M., 1989. Influence of overwintering Daphnia on spring zooplankton communities: an experimental study. Ecol. Res., 4, 323-338.

Hansson L.A., Nicolle A., Brodersen J., Romare P., Skov C. and Brönmark C., 2007. Consequences of fish predation, migration and juvenile ontogeny on zooplankton spring dynamics. Limnol. Oceanogr., 207, 696-706.

Iglesias C., Goyenola G., Mazzeo N., Meerhoff M., Rodó E. and Jeppesen E., 2007. Horizontal dynamics of zooplankton in subtropical Lake Blanca (Uruguay) hosting multiple zooplankton predators and aquatic plant refuges. Hydrobiologia, 584, 179-189.

Lampert W., Lampert K.P. and Larsson P., 2010. Coexisting overwintering strategies in Daphnia pulex: a test of genetic differences and growth responses. Limnol. Oceanogr., 55, 1893-1900.

Lepš J. and Šmilauer P., 2003. Multivariate Analysis of Ecological Data using CANOCO, Cambridge University Press, Cambridge, 284 p.

Lucena-Moya P. and Duggan I.C., 2011. Macrophyte architecture affects the abundance and diversity of littoral microfauna. Aquat. Ecol., 45, 279-287.

McGavigan C., 2012. A quantitative method for sampling littoral zooplankton in lakes: the active tube. Limnol. Oceanogr.-Meth., 10, 289-295.

Nicolle A., Hansson L.-A. and Brönmark C., 2010. Habitat structure and juvenile fish ontogeny shape zooplankton spring dynamics. Hydrobiologia, 652, 119-125.

Norris V., 1993. The use of buffer zones to protect water quality: a review. Water Resour. Manag., 7, 257-272.

Park S.-R., Lee H.-J., Lee S.-W., Hwang S.-J., Byeon M.-S., Joo G.-J., Jeong K.-S., Kong D.-S. and Kim M.-C., 2011. Relationships between land use and multidimensional characteristic of streams and rivers at two different scales. Ann. Limnol. - Int. J. Lim., 47, S107S116.

Pawuła-Piwowarczyk R., 1992. Spatial Management in the Cities and Communes of Wielkopolska Region. (Gospodarka przestrzenna miast i gmin w regionie Wielkopolski), Zakład Poligraficzny Politechniki Poznańskiej, Poznań, 353 p.

Pourriot R., 1970. Quelques Trichocerca (Rotifères) et leurs régimes alimentaires. Ann. Hydrobiol., 1, 155-171.

Pourriot R., 1977. Food and feeding habits of Rotifera. Arch. Hydrobiol. Beiheft, 8, 243-260.

Radwan S., Bielańska-Grajner I. and Ejsmont-Karabin J., 2004. Rotifers Rotifera. Freshwater fauna of Poland (Wrotki Rotifera. Fauna słodkowodna Polski), Oficyna Wydawnicza Tercja, Łódź, 447 p.

Ruttner-Kolisko A., 1980. The abundance and distribution of Filinia terminalis in various types of lakes as related to temperature, oxygen, and food. Hydrobiologia, 73, $169-175$.

Rybak J.I. and Błędzki L.A., 2010. Freshwater Planktonic Crustaceans: Identification key. (Słodkowodne skorupiaki planktonowe), Wydawnictwo Uniwersytetu Warszawskiego, Warszawa, $366 \mathrm{p}$.

Sobczyński T. and Joniak T., 2009. Vertical changeability of physical-chemical features of bottom sediments in three lakes in aspect type of water mixis and intensity of human impact. Pol. J. Environ. Stud., 18, 1093-1099. 
Špoljar M., Dražina T., Šmargač J., Borojevič K.K. and Žutnić, P., 2012. Submerged macrophytes as a habitat for zooplankton development in two reservoirs of a flow-through system (Papuk Nature Park, Croatia). Ann. Limnol. - Int. J. Lim., 48, 161-175.

Stansfield J.H., Perrow M.R., Tench L.D., Jowitt A.J.D. and Taylor A.A.L., 1997. Submerged macrophytes as refuges for grazing Cladocera against fish predation: observations on seasonal changes in relation to macrophyte cover and predation pressure. Hydrobiologia, 342-343, 229-240.

Starmach K., 1989. Plankton roślinny wód słodkich. Metody, badania i klucze do oznaczania gatunków występujących w wodach Europy Środkowej (Freshwater Phytoplankton: Methods and the Identification Key of Central European Species), Vol. I, Polska Akademia Nauk, Polskie Wydawnictwo Naukowe, 496 p.

Sterner R.W., 1989. The role of grazers in phytoplankton succession. In: Sommer U. (ed.), Plankton Ecology: Succession in Plankton Communities, Springer, New York, 107-170.
Symons C.C., Arnott S.E. and Sweetman J.N., 2012. Grazing rates of crustacean zooplankton communities on intact phytoplankton communities in Canadian Subarctic lakes and ponds. Hydrobiologia, 694, 131-141.

Tessier C., Cattaneo A., Pinel-Alloul B., Galanti G. and Morabito G., 2004. Biomass, composition and size structure of invertebrate communities associated to different types of aquatic vegetation during summer in Lago di Candia (Italy). J. Limnol., 63, 190-198.

Tinson S. and Laybourn-Parry J., 1985. The behavioural responses and tolerance of freshwater benthic cyclopoid copepods to hypoxia and anoxia. Hydrobiologia, 127, 257-263.

Tõnno I., Künnap H. and Nõges T., 2003. The role of zooplankton grazing in the formation of 'clear water phase' in a shallow charophyte-dominated lake. Hydrobiologia, 506-509, 353-358.

Warfe D.M. and Barmuta L.A., 2004. Habitat structural complexity mediates the foraging success of multiple predator species. Oecologia, 141, 171-178. 